See discussions, stats, and author profiles for this publication at: https://www.researchgate.net/publication/342004276

\title{
Makian Bahasa Wakatobi Dialek Kaledupa
}

\section{Article · May 2020}

DOI: 10.26499/jk.v16i1.141

1 author:

2usiati Susiati

Universitas iqra buru

30 PUBLICATIONS 109 CITATIONS

SEE PROFILE

Some of the authors of this publication are also working on these related projects:

Project Sastra View project

Project Linguist View project 
K A N D A I

\begin{tabular}{|l|l|r|}
\hline Volume 16 & No. 1, Mei 2020 & Halaman 27-43 \\
\hline
\end{tabular}

\title{
MAKIAN BAHASA WAKATOBI DIALEK KALEDUPA (Invective Wakatobi Language Kaledupa Dialect)
}

\author{
Susiati, Darwis Buton, \& Udayanto \\ Universitas Iqra Buru \\ Jalan Prof. Dr. H. A. R. Bassalamah, M.Si., Namlea, Indonesia \\ susiatiuniqbu@gmail.com
}

(Diterima: 9 Mei 2019; Direvisi: 25 Februari 2020; Disetujui: 21 April 2020)

\begin{abstract}
This study aimed to describe the inverse type of Wakatobi Kaledupa dialect. This research was a qualitative research. Data were collected using observation methods with moderate participatory observation techniques, recording techniques, and note taking techniques. Data were analyzed descriptively according to Wijana's. The results showed that there were fifteen types of Wakatobi language dialects in the dialect, namely (1) invective related to religion/belief; (2) invective related to unseen; (3) invective related to sex; (4) invective relating to parts of the body; (5) invective relating to bodily functions; (6) invective relating to body shape; (7) synonym for the word stupid; (8) invective relating to the name of the animal; (9) invective relating to the name of an ignorant person; (10) invective related to kinship; (11) invective relating to low professions; (12) invective related to ethnicity; (13) invective relating to the origin of remote areas; (14) invective relating to abstract objects; (15) invective related to a disease that affects the subject. Various types of invective are found in linguistic devices such as words, phrases, and grammatical forms.

Keywords: invective, type, Wakatobi language, Kaledupa dialect
\end{abstract}

\begin{abstract}
Abstrak
Penelitian ini bertujuan mendeskripsikan jenis makian bahasa Wakatobi dialek Kaledupa. Penelitian ini merupakan penelitian kualitatif. Data dikumpulkan menggunakan metode observasi dengan teknik observasi partisipatif moderat, teknik rekam, dan teknik catat. Data dianalisis secara deskriptif sesuai dengan teori makian Wijana. Hasil penelitian menunjukkan bahwa jenis makian bahasa Wakatobi dialek Kaledupa ada lima belas, yakni (1) makian yang bertalian dengan agama/kepercayaan; (2) makian yang bertalian dengan gaib; (3) makian yang bertalian dengan kelamin; (4) makian yang bertalian dengan bagian tubuh; (5) makian yang bertalian dengan fungsi tubuh; (6) makian yang bertalian dengan bentuk tubuh; (7) sinonim kata bodoh; (8) makian yang bertalian dengan nama binatang; (9) makian yang bertalian dengan nama orang dungu; (10) makian yang bertalian dengan kekerabatan; (11) makian yang bertalian dengan profesi rendah; (12) makian yang bertalian dengan suku/etnis; (13) makian yang bertalian dengan asal daerah terpencil; (14) makian yang bertalian dengan benda abstrak; (15) makian yang bertalian pada penyakit yang menjangkiti subjek. Berbagai jenis makian tersebut ditemukan dalam bentuk piranti linguistik seperti kata, frasa, dan bentuk gramatikal.
\end{abstract}

Kata-kata kunci: makian, jenis, bahasa Wakatobi, dialek Kaledupa

DOI: 10.26499/jk.v16i1.1413

How to cite: Susiati, Buton, D., \& Udayanto (2020). Makian bahasa Wakatobi dialek Kaledupa. Kandai, 16(1), 27-43 (DOI: 10.26499/jk.v16i1.1413) 


\section{PENDAHULUAN}

Makian atau umpatan secara disengaja maupun tidak disengaja sering ditemukan dalam kehidupan sehari-hari saat berinteraksi. Kemunculannya pun dalam konteks yang berbeda-beda, misalnya saat bertikai, bercanda, mengejek, menyindir, menyatakan kekaguman, dan sebagainya. Umpatan bukan hanya terdapat dalam bahasa Indonesia, pada bahasa daerah pun ditemukan umpatan-umpatan yang melebihi jumlah umpatan dalam bahasa Indonesia. Salah satunya dalam bahasa Wakatobi dialek Kaledupa.

Fenomena bahasa makian dalam bahasa Wakatobi dialek Kaledupa sangat beragam dan memungkinkan setiap orang untuk menyesuaikan dirinya dengan lingkungan fisik dan lingkungan sosial dalam memperlajari kebiasaan, adat istiadat, kebudayaan, dan latar belakang masing-masing. Munculnya makian saat bertutur sering dipengaruhi oleh konteks yang menyertai tuturan tersebut. Misalnya, si A bercanda kepada si B tidak menutup kemungkinan ada tuturan makian yang menyertai proses interaksi mereka. Hal ini, menjadi sesuatu yang biasa karena penggunaan makian dalam berinteraksi dapat berfungsi sebagai senda gurau.

Susiati (2018, hlm. 110) mengatakan bahwa bahasa Kepulauan Tukang Besi atau sekarang dikenal dengan bahasa Wakatobi adalah bahasa yang digunakan oleh masyarakat di Kabupaten Wakatobi. Kabupaten Wakatobi merupakan akronim dari empat gugus pulau, yakni pulau Wangiwangi, Kaledupa, Tomia, dan Binongko. Bahasa Wakatobi merupakan bahasa yang digunakan oleh penduduk asli Wakatobi dan merupakan bahasa pertama atau bahasa ibu mereka. Kedudukan bahasa Wakatobi sangat penting dalam kehidupan masyarakat karena dominan masyarakat Wakatobi masih kental menggunakan bahasa Ibu mereka.

Kisyani (2004, hlm. 27) menyatakan bahwa dalam percakapan sehari-hari kata makian muncul sebagai sebuah ekspresi komunikasi. Meski sering disebut tidak sopan, tidak etis, dan tidak beretika tetapi kata makian merupakan bagian dari suatu bahasa atau tuturan. Makian adalah ungkapan yang secara spontan dilontar oleh seseorang ketika mengalami suatu tekanan dan cenderung bermakna kurang baik. Sama halnya dengan Winarsih (2010, hlm. 23) yang menyatakan bahwa makian merupakan kata-kata kotor yang diucapkan oleh seseorang. Kotor berarti mencakup hal yang bersifat tidak sopan, keji, jorok, menjijikkan, dan pelanggaran kesusilaan.

Kata-kata makian lahir dari sebuah jenjang bahasa yang mencerminkan dan melestarikan strata atau penggolongan masyarakat berdasarkan kelas, usia, dan profesi dalam masyarakat karena dalam masyarakat terdapat kategori tingkatan kesopanan dalam bertutur, yakni tuturan kasar, sedang, dan halus. Makian tergolong dalam bahasa kasar, tetapi makian tersebut disesuaikan dengan konteks yang menyertainya. Makian dilontarkan oleh penutur karena memiliki fungsi tertentu. Fungsi tersebut juga dapat dikatakan sebagai motif ekspresi saat mereka memaki. Adapun fungsi-fungsi makian yang dimaksud adalah kemarahan, kekesalan, kesedihan, kekaguman, penyesalan, keheranan, penghinaan atau merendahkan, keterkejutan, keakraban atau humor, dan kegembiraan.

Ideologi kebahasaan dalam masyarakat bersifat multikultural dan bilingualisme. Kadang-kadang para pelaku salah menafsirkan suatu bahasa dari satu komunitas dengan komunitas yang lain karena sejatinya pelaku bahasa 
belum mengetahui gagasan/ide-ide, cara beradaptasi, dan bersosialisasi dalam suatu komunitas tertentu. Bahasa bukan semata-mata persoalan gramatikal, leksikal, ataupun ejaan tetapi bahasa ketika dipakai dalam berkomunikasi antara dua orang atau lebih terdapat unsur yang berpatokan pada status para pelaku bahasa, hubungan antarpenutur dan petutur, konteks, dan ranah emosional.

Bahasa makian pada masyarakat Kaledupa penggunaannya merupakan suatu hal yang lumrah tetapi tetap melihat status sosial dan usia penutur dan petutur. Misalnya, seorang anak kecil saat melontarkan makian kepada lawan tuturnya yang berusia lebih tua tergolong hal yang tidak sopan walaupun dalam konteks apapun. Namun, jika orang tua mengeluarkan kata-kata makian kepada lawan tuturnya yang berusia lebih muda darinya dapat kategorikan sopan bergantung dari konteks yang menyertainya.

Penelitian ini bertujuan untuk mendeskripsikan jenis makian dalam bahasa Wakatobi dialek Kaledupa.

\section{LANDASAN TEORI}

\section{Makian}

Dalam KBBI (Alwi, et al., 2008, hlm. 702), "maki" diartikan sebagai 'mengeluarkan kata-kata (ucapan) keji (kotor, kasar, dan sebagainya) sebagai pelampiasan kemarahan atau rasa jengkel'; "memaki" diartikan 'mengucapkan kata-kata keji, tidak pantas, kurang adat untuk menyatakan kemarahan atau kejengkelan'; "makian" diartikan 'kata keji yang diucapkan karena marah dan sebagainya'.

Anderson dan David (2010, hlm. 5) mengatakan bahwa terdapat tiga syarat agar suatu kata atau ungkapan dapat dikelompokkan sebagai kata makian, yaitu

1. merujuk pada tabu atau stigma (tanda dari ketidakberterimaan social dalam suatu lingkungan budaya);

2. tidak dapat ditafsirkan secara harfiah; dan

3. dapat digunakan untuk mewujudkan emosi dan sikap yang kuat.

Edward (dalam Jannah, et al., 2017, hlm. 47) menyatakan bahwa kata makian merupakan ungkapan untuk menyinggung harga diri orang lain yang menjadi sasaran adalah menyakiti hatinya dan untuk sementara waktu atau karena kebutuhan yang tidak jelas sehingga kadang-kadang yang memaki tidak mengetahui arti sebenarnya yang terkandung dalam kata itu. Sama halnya dengan yang diungkapkan oleh Morehead (dalam Jannah, et al., 2017, hlm. 47) yang mengatakan bahwa kata makian adalah sumpah serapah.

Triadi (2017, hlm. 1) mengatakan bahwa makian tidak hanya ditemukan dalam interaksi sosial secara langsung di masyarakat, tetapi makian juga sudah menyebar dalam dunia maya, misalnya Facebook. Dari hasil penelitiannya, menunjukkan bahwa penggunaan makian para pelaku bahasa di dunia maya mempunyai karakteristik yang sama dengan dengan penggunaan variasi dan ragam makian bila dilihat dari tingkat sosial masyarakat.

Webster's New World Dictionary (Neufeldt dan Guralnik dalam Jannah, et al., 2017, hlm. 47), makian memiliki beberapa arti, yaitu

1. membuat pernyataan serius dengan memohon kepada Tuhan atau sesuatu yang dianggap suci untuk memberikan sumpah atas nama seseorang;

2. membuat janji yang serius;

3. menggunakan bahasa yang tidak senonoh atau cabul, mengutuk; 
4. berdalil untuk memberikan bukti di bawah sumpah.

\section{Bentuk Makian}

Wijana dan Rohmadi (2006, hlm. 32), bentuk-bentuk makian dalam bahasa Indonesia, yakni:

1. makian berbentuk kata;

2. makian berbentuk frasa; dan

3. makian berbentuk klausa.

$$
\text { Referensi makian bahasa }
$$

Indonesia, yakni:

1. keadaan,

2. binatang,

3. makhluk halus,

4. benda-benda,

5. bagian tubuh,

6. kekerabatan, dan

7. profesi.

Wijana dan Rohmadi (2006, hlm. 125) menjelaskan bahwa bentuk-bentuk makian adalah sarana kebahasaan yang dibutuhkan oleh para penutur untuk mengekspresikan ketidaksenangan dan mereaksi berbagai fenomena yang menimbulkan perasaan seperti itu. Bentuk-bentuk kebahasan ini secara formal dapat dibedakan menjadi tiga jenis, yakni makian berbentuk kata, berbentuk frasa (kelompok kata), dan klausa. Berikut ini penjelasan dari masing-masing jenis makian dilihat dari bentuk piranti linguistiknya.

\section{Makian Bentuk Kata}

Makian berbentuk kata dapat dibedakan menjadi dua, yaitu makian bentuk kata dasar dan makian bentuk kata turunan atau kata jadian. Makian bentuk dasar adalah makian yang berwujud kata-kata, seperti babi, bangsat, setan, dan sebagainya. Sementara itu, makian yang berbentuk jadian adalah makian yang berupa katakata polimorfemik. Makian yang berbentuk kata turunan atau jadian ini terbagi menjadi tiga jenis, yakni makian berafiks, makian bentuk ulang, dan makian bentuk majemuk. Makian berafiks misalnya kata sialan, bajingan, kampungan, diancuk, dan diamput. Selanjutnya, makian bentuk ulang adalah sebuah makian yang mendapatkan proses reduplikasi, misalnya kata babibabi, anjing-anjing atau cecunguk (reduplikasi parsial). Sedangkan untuk makian yang berbentuk proses pemajemukan adalah gabungan dua kata yang memiliki makna dari unsur pembentuknya, misalnya kurang ajar, cuki mai, buaya darat, setan alas, tuluy keparat dan sebagainya.

\section{Makian Bentuk Frasa}

Terdapat dua bentukan yang digunakan untuk membentuk frasa makian dalam bahasa Indonesia, yakni dasar bergabung makian, seperti dasar sial, dasar kampungan, dan makian plus mu, seperti matamu, kakekmu. Kata dasar dalam hal ini memungkinkan melekat dengan berbagai makian dengan referensi seperti binatang: dasar buaya, dasar babi, dasar kambing, dan sebagainya; profesi: dasar pelacur, dasar sundal, dan sebagainya; benda: dasar tai, dasar comberan, dan sebagainya; keadaan: dasar gila, dasar keparat, dasar sinting, dasar gelo, dan sebagainya; dan makhluk halus: dasar setan, dasar iblis, dasar tuyul, dasar kunti, dan sebagainya.

\section{Makian Bentuk Klausa}

Makian yang berbentuk klausa dalam bahasa Indonesia pada umumnya dibentuk dengan menambahkan pronomina di belakang makian, seperti gila kamu, setan kamu, sundal kamu, gila bener dia. Adapun contoh penggunaannya sebagai berikut.

- Gila kamu, Ayahmu sendiri kamu umpat seperti itu

- Setan kamu, sekarang kamu tak kuberi ampun. 
- Udah dibantu malah gitu, dasar tolol kamu.

- Haduh sudah dikasih hati malah minta jantung, Dasar tai!

- Kalian memang tidak ada otaknya, Kutu kupret kalian.

Wijana dan Rohmadi (2006, hlm. 119) menyebutkan bahwa dilihat dari referensinya, sistem makian dalam bahasa Indonesia dapat dibedakan bermacam-macam, yakni keadaan, binatang, mahluk halus, benda-benda, bagian tubuh, kekerabatan, dan profesi. Adapun penjelasan dari masing-masing referensi tersebut sebagai berikut.

1. Keadaan

Kata-kata yang menunjukan keadaan yang tidak menyenangkan agaknya merupakan satuan lingual yang paling umum dimanfaatkan untuk mengungkapkan makian. Secara garis besar ada tiga hal yang dapat atau mungkin dihubungkan dengan keadaan yang tidak menyenangkan ini, yaitu keadaan mental, seperti gila, idiot, sinting, bodoh, tolol, dan sebagainya. Selanjutnya, berbicara keadaan yang tidak direstui tuhan atau agama, seperti keparat, jahanam, terkutuk, kafir, najis, dan sebagainya. Makian jenis ini digunakan ketika seseorang sudah sangat kesal, sehingga makian ini menimbulkan sikap yang sangat terasa bagi lawan tutur yang menjadi sasaran makian tersebut.

Selanjutnya, keadaan yang berhubungan dengan peristiwa tidak menyenangkan yang menimpa seseorang, seperti celaka, mati, modar, sialan, kampret, dan sebagainya. Dalam hal ini, sering pula beberapa di antara kata-kata ini digunakan untuk mengekspresikan keterkejutan, keheranan, kekaguman, dan sebagainya.

2. Binatang

Satuan lingual yang referensinya binatang pemakaiannya bersifat metaforis. Artinya, hanya sifat-sifat tertentu dari binatang itulah yang memiliki kemiripan atau kesamaan dengan individu atau keadaan yang dijadikan sasaran makian. Dalam hal ini, tentu saja tidak semua binatang dapat digunakan untuk sarana memaki dalam penggunaan bahasa.

Berdasarkan pengamatan sekilas binatang-binatang yang dipilih atau digunakan sebagai kata-kata makian dalam bahasa Indonesia adalah binatangbinatang yang memiliki sifat tertentu. Sifat-sifat yang menjijikan (anjing), menjijikan dan diharamkan oleh salah satu agama (babi), mengganggu (bangsat), menyakiti atau mencari kesenangan di atas penderitaan (lintah), senang cari pasangan (buaya dan bandot), banyak bicara (beo). Referen kata-kata tersebut bila digunakan sebagai makian, tentu saja sifat-sifat itu kemudian diterapkan kepada manusia. Selain itu, ada dua buah kata ragam nonformal atau cakapan yang sering digunakan untuk keperluan ini sehubungan dengan keburukan referennya, yakni monyet dan kunyuk.

3. Makhluk Halus

Tiga buah kata yang lazim digunakan untuk melontarkan makian yang mengacu pada mahluk halus adalah kata setan, setan alas, dan iblis. Kesemuanya adalah mahluk-mahluk halus yang sering mengganggu kehidupan manusia. Selain itu, kata tuyul sering digunakan kepada sikap seseorang yang sering menguntil atau menipu.

4. Benda-benda

Tidak jauh berbeda dengan namanama binatang dan mahluk halus, namanama benda yang lazim digunakan untuk memaki juga berkaitan dengan keburukan referennya, seperti bau tidak sedap (tai dan tai kucing), kotor dan usang (gembel), dan suara yang menggangu (sompret).

5. Bagian Tubuh

Anggota tubuh yang lazim diucapkan untuk mengekspresikan 
makian adalah anggota tubuh yang erat dengan aktivitas seksual ini sangat bersifat personal, dan dilarang dibicarakan secara terbuka kecuali di forum-forum tertentu.

Bentuk lingual yang sering dimanfaatkan oleh penutur bahasa Indonesia adalah kata puki mai dan cuki mai. Bagian tubuh lainnya yang sering digunakan untuk memaki dalam bahasa Indonesia adalah mata dalam bentuk frase matamu. Kata ini dipakai untuk mengumpat orang yang tidak memanfaatkan alat penglihatannya sehingga melakukan kesalahan. Contoh: Matamu, sudah pasang tanda kok ditabrak.

Frasa lainnya adalah hidung belang dan mata duitan yang secara berturut-turut digunakan secara figuratif untuk memaki laki-laki yang mudah berganti-ganti pasangan dan orang yang lebih mementingkan uang dalam mengerjakan sesuatu.

6. Kekerabatan

Sejumlah kata-kata kekerabatan mengacu pada individu yang dihormati atau biasanya mengajarkan hal-hal yang baik kepada generasi berikutnya, seperti ibu, bapak, kakek, nenek, dan sebagainya. Sebagai penanda individu yang dihormati, kata-kata itu tabu untuk disebut-sebut tidak pada tempatnya. Akan tetapi, kata tersebut diucapkan untuk mengumpat atau mengungkapkan kejengkelan kepada lawan bicaranya. Penutur bahasa Indonesia sering kali membawa dan menambahkan klitik-mu di belakangnya, seperti kakekmu, nenekmu, bapakmu, dan sebagainya. Contohnya: Memangnya ini jalan nenekmu!

\section{Profesi}

Profesi seseorang, terutama profesi rendah dan yang diharamkan oleh agama, sering kali digunakan oleh para pemakai bahasa untuk mengumpat atau mengekspresikan rasa jengkelnya.
Profesi-profesi itu di antaranya maling, sundal, bajingan, copet, lonte, cecenguk, dan sebagainya.

\section{Ciri-ciri Makian}

Jannah, et al. (2017, hlm. 48) ciriciri kata makian sebagai berikut.

1. Merupakan ungkapan perasaan tertentu yang tumbuh disebabkan oleh dorongan yang bersifat kebahasaan dan nonkebahasaan.

2. Saluran dari emosi dan sikap pembicara.

3. Menggunakan kata-kata tabu, kasar, kotor, cabul, tidak sopan, dan keji.

4. Merujuk pada tabu atau stigma dalam suatu lingkungan budaya/masyarakat.

5. Ungkapan untuk menyinggung harga diri orang lain dan menyakiti hati.

6. Sumpah serapah.

7. Diucapkan karena marah.

Dalam konteks tertentu dapat digunakan sebagai penanda keintiman dan pernyataan identitas.

\section{METODE PENELITIAN}

\section{Jenis Penelitian dan Pendekatan}

Penelitian ini merupakan jenis penelitian deskriptif kualitatif dengan menggunakan pendekatan sosiolinguistik. Jenis penelitian deskriptif kualitatif, yakni salah satu prosedur penelitian yang menghasilkan data deskriptif berupa ucapan atau tulisan dan perilaku orang-orang yang diamati (Moleong, 2007, hlm. 44). Sementara, pendekatan sosiolinguisik, yaitu membahas hubungan antara pemakaian bahasa dan perilaku bahasa. Dengan membahas pemakaian bahasa, seseorang akan dapat mengetahui berbagai kondisi, nilai-nilai, kepercayaan, sistem etika, aturan, dan 
lain-lain yang membentuk dan memberikan ciri khusus kepada kelompok-kelompok masyarakat pemakai bahasa tersebut atau aspekaspek kemasyarakatan bahasa, khususnya perbedaan-perbedaan yang terdapat di dalam bahasa yang berkaitan dengan faktor-faktor bahasa.

\section{Metode dan Teknik Pengumpulan Data}

Metode pengumpulan data dalam penelitian ini adalah metode observasi. Kartono (1980, hlm. 142) observasi adalah studi yang disengaja dan sistematis tentang fenomena dan gejalagejala psikis dengan jalan pengamatan dan pencatatan. Observasi diarahkan pada kegiatan memperhatikan secara akurat, mencatat fenomena yang muncul, mempertimbangkan hubungan antara aspek dalam fenomena, dan dilakukan dengan cara mengamati objek kajian dalam konteksnya.

Metode ini digunakan untuk mendapatkan data lisan, yaitu berupa makian bahasa Wakatobi dialek Kaledupa. Teknik-teknik yang digunakan untuk melengkapi metode observasi tersebut adalah sebagai berikut.

1. Teknik Observasi Partisipasi

Melakukan kegiatan menyadap dengan berpartisipasi dalam pembicaraan, menyimak pembicaraan. Observasi partisipasi (participant observation) adalah teknik pengumpulan data yang digunakan untuk menghimpun data penelitian melalui pengamatan dan penginderaan. Peneliti benar-benar terlibat dalam keseharian responden. Sibarani (2004, hlm. 54) metode observasi partisipasi ialah ikut berpartisipasi dalam kegiatan yang diobservasi, dideskripsi, dan dianalisis.

Jenis teknik observasi partisipasi yang digunakan dalam penelitian ini adalah partisipasi yang moderat (moderate participation). Peneliti dalam mengumpulkan data ikut berpartisipasi dalam beberapa kegiatan tetapi tidak semuanya.

2. Teknik Rekam

Teknik ini digunakan untuk merekam peristiwa-peristiwa yang secara potensial banyak menggunakan tuturan yang mengandung kata-kata makian.

\section{Teknik Catat}

Dari hasil rekaman dan data-data berupa tuturan emosi yang diucapkan responden yang dicatat, selanjutnya diseleksi dan diidentifikasi berdasarkan jenis makian bahasa Wakatobi dialek Kaledupa tersebut.

\section{Sumber dan Jenis Data}

Sumber data dalam penelitian ini adalah masyarakat asli Kaledupa. Jenis data dalam penelitian ini adalah tuturan yang mengandung kata atau kalimat makian dalam bahasa Wakatobi dialek Kaledupa.

\section{Teknis Analisi Data}

Penelitian kualitatif memungkinkan dilakukan analisis data pada waktu peneliti berada di lapangan maupun setelah kembali dari lapangan. Pada penelitian ini, analisis data dilaksanakan bersamaan dengan proses pengumpulan data. Adapun langkahlangkah analisis penelitian ini adalah sebagai berikut.

1. Penyeleksian Data

Makian bahasa Wakatobi dialek Kaledupa yang terdapat dalam rekaman diseleksi yang termasuk dalam jenis makian bahasa Wakatobi dialek Kaledupa.

2. Pengklasifikasian Data

Penggolongan data hasil seleksi diidentifikasi berdasarkan pada fokus 
masalah yang termasuk dalam jenis makian bahasa Wakatobi dialek Kaledupa.

3. Penganalisisan Data

Data yang telah diklasifikasi kemudian dianalisis dengan mendeskripsikan secara mendetail permasalahan yang terdapat dalam data yang telah dikumpulkan berdasarkan teori yang berkaitan dengan jenis makian bahasa Wakatobi dialek Kaledupa sebagai dasar pedoman dalam menganalisis.

4. Penyimpulan Hasil Analisis

Penyimpulan terhadap semua fokus masalah jenis sebagai karakteristik makian bahasa Wakatobi dialek Kaledupa.

\section{PEMBAHASAN}

Adapun berbagai referensi yang menjadi rujukan dalam penelitian ini adalah dari penelitia-penelitian terdahulu, yakni (1) Jannah, dkk. (2017:43) dengan judul penelitiannya "Bentuk dan Makna Kata Makian di Terminal Purabaya Surabaya dalam Kajian Sosiolinguistik". Hasil dari penelitian ini menunjukkan bahwa warga terminal Purabaya, Surabaya, kebanyakan menggunakan makian berbentuk kata hampir tujuh puluh lima persen, sedangkan yang lima belas persen menggunakan makian berbentuk frase; (2) penelitian Kusmana dan Asria (2018) yang berjudul "Analisis Ungkapan Makian dalam Bahasa Kerinci: Studi Sosiolinguistik". Adapun permasalahan yang diangkat dalam penelitian ini adalah bentuk dan karakteristik ungkapan makian dalam bahasa Kerinci serta faktor yang memengaruhi munculnya makian dalam bahasa Kerinci. Hasil penelitiannya membuktikan bahwa hasil bentuk dan karakteristik makian dalam bahasa Kerinci meliputi bentuk keadaan, kekerabatan, binatang, makhluk halus, bagian tubuh, profesi, dan seruan. Sedangkan faktor yang memengaruhi munculnya makian tersebut, yakni faktor sosial dan situasional (Kusmana dan Asria, 2018, hlm. 173).

Merujuk pada penelitian yang terdahulu dan sesuai dengan permasalahan dalam penelitian ini, yakni mendeskripsikan jenis makian dalam bahasa Wakatobi dialek Kaledupa, maka akan dijelaskan sebagai berikut.

\section{Jenis Makian Bahasa Wakatobi Dialek Kaledupa}

Jenis makian bahasa Wakatobi dialek Kaledupa yang ditemukan dalam penelitian ini meliputi lima belas jenis, yaitu (1) makian yang bertalian dengan agama/kepercayaan; (2) makian yang bertalian dengan gaib; (3) makian yang bertalian dengan kelamin; (4) makian yang bertalian dengan bagian tubuh; (5) makian yang bertalian dengan fungsi tubuh; (6) makian yang bertalian dengan bentuk tubuh; (7) sinonim kata bodoh; (8) makian yang bertalian dengan nama binatang; (9) makian yang bertalian dengan nama orang dungu; (10) makian yang bertalian dengan kekerabatan; (11) makian yang bertalian dengan profesi rendah; (12) makian yang bertalian dengan suku/etnis; (13) makian yang bertalian dengan asal daerah terpencil; (14) makian yang bertalian dengan benda abstrak. Berbagai jenis makian tersebut ditemukan dalam bentuk piranti linguistik seperti kata, frasa, dan bentuk gramatikal; (15) makian yang bertalian dengan penyakit yang menjangkiti subjek.

Untuk lebih jelasnya, tujuh jenis makian bahasa Wakatobi dialek Kaledupa dapat dilihat pada tabel berikut. 
Tabel 1

Jenis Makian Bahasa Wakatobi Dialek Kaledupa

\begin{tabular}{|c|c|c|c|c|}
\hline No & JenisMakian & Kata Makian & $\begin{array}{c}\text { Bentuk Piranti } \\
\text { Linguistik }\end{array}$ & Makna \\
\hline \multirow[t]{3}{*}{1} & \multirow{3}{*}{$\begin{array}{l}\text { Makian yang bertalian } \\
\text { dengan } \\
\text { agama/kepercayaan }\end{array}$} & Kaffiri & Kata nomina & Kafir \\
\hline & & Jahannamu & Kata adjektiva & Jahanam \\
\hline & & Haramu & Kata nomina & Haram \\
\hline \multirow[t]{5}{*}{2} & \multirow{5}{*}{$\begin{array}{l}\text { Makian yang bertalian } \\
\text { dengan makhluk gaib }\end{array}$} & Settani & Kata nomina & Setan \\
\hline & & Ibilisi & Kata nomina & Iblis \\
\hline & & Onitu & Kata nomina & Hantu \\
\hline & & Onituda'o & Frasa nomina & $\begin{array}{l}\text { Hantu jahat (buruk } \\
\text { rupa) }\end{array}$ \\
\hline & & Pongko & Kata nomina & Parakang \\
\hline \multirow[t]{5}{*}{3} & \multirow{5}{*}{$\begin{array}{l}\text { Makian yang bertalian } \\
\text { dengan kelamin }\end{array}$} & Uni & Kata nomina & Kelamin perempuan \\
\hline & & Buta & Kata nomina & Kelamin perempuan \\
\hline & & Lombu nu uni & Frasa nomina & $\begin{array}{l}\text { Lubang kemaluan } \\
\text { perempuan }\end{array}$ \\
\hline & & Lombu nu sio & Frasa nomina & Lubang dubur \\
\hline & & Gora'u & Kata nomina & Kelamin laki-laki \\
\hline \multirow[t]{9}{*}{4} & \multirow{9}{*}{$\begin{array}{l}\text { Makian yang bertalian } \\
\text { dengan bagian tubuh }\end{array}$} & Kapala & Kata nomina & Kepala \\
\hline & & Fatu nu kapala & Frasa nomina & Batu kepala \\
\hline & & Бobo & Kata nomina & Hidung \\
\hline & & Ngaro & Kata nomina & Lubang mulut \\
\hline & & Tobutu & Kata nomina & Buntut \\
\hline & & Tuli & Kata nomina & Telinga \\
\hline & & Fatu koni & Frasa nomina & Batu gigi \\
\hline & & Ella pe’'i & Frasa nomina & Anak tekak \\
\hline & & Kohoru & Kata nomina & Gusi \\
\hline \multirow[t]{6}{*}{5} & \multirow{6}{*}{$\begin{array}{l}\text { Makian yang bertalian } \\
\text { dengan fungsi tubuh }\end{array}$} & Mengusu & Gramatikal & Cerewet \\
\hline & & Pande fila & Frasa adjektiva & Tukang jalan \\
\hline & & Tuduhi & Kata verba & Tending \\
\hline & & Fekke & Kata verba & \\
\hline & & Pappotaru & Gramatikal (adjektiva) & Tukang judi \\
\hline & & Pabbisara & Gramatikal (adjektiva) & Tukang bicara/cerewet \\
\hline \multirow[t]{19}{*}{6} & \multirow{19}{*}{$\begin{array}{l}\text { Makian yang bertalian } \\
\text { dengan bentuk tubuh }\end{array}$} & deppe & Kata adjektiva & Pesek \\
\hline & & Bombo & Kata adjektiva & Gemuk \\
\hline & & Rabe & Kata adjektiva & Bibir memble \\
\hline & & Pesso & Kata adjektiva & Miring \\
\hline & & Leppa & Kata adjektiva & Kepang \\
\hline & & Ulli & Kata adjektiva & Pantat besar \\
\hline & & Kajilo & Kata adjektiva & Juling \\
\hline & & Bota & Kata adjektiva & Botak \\
\hline & & Foka to'oge & Frasa adjektiva & Jidat besar \\
\hline & & Janda talinga & Frasa adjektiva & Telinga lebar \\
\hline & & Morusu & Kata adjektiva & Kurus \\
\hline & & Kabongo & Kata adjektiva & Tuli \\
\hline & & Koppe & Kata adjektiva & Tirus \\
\hline & & Busulub5a & Kata adjektiva & Gemuk \\
\hline & & Dhobba & Kata adjektiva & Gemuk \\
\hline & & Ase'o & Kata adjektiva & Dagu \\
\hline & & $P u d u$ & Kata adjektiva & Pendek \\
\hline & & Puru gengge & Frasa adjektiva & Rambut kriting \\
\hline & & Bota & Kata adjektiva & Botak \\
\hline
\end{tabular}




\begin{tabular}{|c|c|c|c|c|}
\hline \multirow[t]{6}{*}{7} & \multirow{6}{*}{$\begin{array}{l}\text { Makian yang bersinonim } \\
\text { dengan kata bodoh }\end{array}$} & $P e^{\prime} i$ & Kata adjektiva & Bodoh \\
\hline & & КаБео-Бео & Kata adjektiva & Bodoh \\
\hline & & Kapatuli & Kata adjektiva & Bodoh \\
\hline & & Goba & Kata adjektiva & Bodoh \\
\hline & & Kura & Kata adjektiva & Bodoh \\
\hline & & Ota rense & Frasa adjektiva & Otak lumpur \\
\hline \multirow[t]{10}{*}{8} & \multirow{10}{*}{$\begin{array}{l}\text { Makian yang bertalian } \\
\text { dengan nama binatang }\end{array}$} & $\mathrm{Obu}$ & Kata nomina & Anjing \\
\hline & & Obu uta & Frasa nomina & Anjing hutan \\
\hline & & beka & Kata nomina & Kucing \\
\hline & & Kadadi & Kata nomina & Burung \\
\hline & & Mia uta & Kata nomina & Orang utan \\
\hline & & Ndoke & Kata nomina & Monyet \\
\hline & & Kumbou & Kata nomina & Biawak \\
\hline & & Bueya & Kata nomina & Buaya \\
\hline & & $S a^{\prime} a$ & Kata nomina & Ular \\
\hline & & Ranggaja & Kata nomina & Kepiting lumpur \\
\hline \multirow[t]{4}{*}{9} & \multirow{4}{*}{$\begin{array}{l}\text { Makian yang bertalian } \\
\text { dengan nama orang } \\
\text { bodoh, gila, dan dungu. }\end{array}$} & Anjo & Kata nomina & \\
\hline & & Ambe & Kata nomina & \\
\hline & & Dakku & Kata nomina & \\
\hline & & La teke & Kata nomina & \\
\hline \multirow[t]{3}{*}{10} & \multirow{3}{*}{$\begin{array}{l}\text { Makian yang bertalian } \\
\text { dengan kekerabatan }\end{array}$} & Ama'u & Kata nomina & Bapakmu \\
\hline & & Ina'u & Kata nomina & Mamamu \\
\hline & & Отри'и & Kata nomina & Kakekmu/nenekmu \\
\hline \multirow[t]{5}{*}{11} & \multirow{5}{*}{$\begin{array}{l}\text { Makian yang bertalian } \\
\text { dengan profesi rendah }\end{array}$} & Pappotaru & Kata nomina & Penjudi \\
\hline & & Pammoro'u & Kata nomina & Peminum \\
\hline & & Pabboke & Kata nomina & Penyabung \\
\hline & & Paffofine & Kata nomina & Tukang perempuan \\
\hline & & Pammo'ane & Kata nomina & Tukang laki-laki \\
\hline 12 & $\begin{array}{l}\text { Makian yang bertalian } \\
\text { dengan suku/etnis }\end{array}$ & Fadu & Kata nomina & Suku Bajo \\
\hline \multirow[t]{2}{*}{13} & \multirow{2}{*}{$\begin{array}{l}\text { Makian yang bertalian } \\
\text { dengan asal daerah } \\
\text { terpencil }\end{array}$} & Ammai Kollo & Frasa nomina & Orang hutan \\
\hline & & Ammai furake & Frasa nomina & Orang Furake \\
\hline \multirow[t]{4}{*}{14} & \multirow{4}{*}{$\begin{array}{l}\text { Makian yang bertalian } \\
\text { dengan benda abstrak }\end{array}$} & Kalea & Nomina abstrak & \\
\hline & & Tajo & Nomina abstrak & \\
\hline & & Kaleppa & Nomina abstrak & \\
\hline & & Kabulu & Nomina abstrak & \\
\hline \multirow[t]{3}{*}{15} & \multirow{3}{*}{$\begin{array}{l}\text { Makian yang bertalian } \\
\text { dengan penyakit yang } \\
\text { menjangkiti subjek }\end{array}$} & Sappa & Kata nomina & Asma \\
\hline & & Pamo & Kata nomina & Panu \\
\hline & & Leppa & Kata nomina & \\
\hline
\end{tabular}

\section{Makian yang Bertalian dengan}

\section{Agama/Kepercayaan}

Makian ini dituturkan dengan menyebutkan sesuatu sikap yang tidak dibenarkan dalam agama. Tujuan makian ini dituturkan karena emosi, marah, keakraban, dan kekesalan terhadap lawan tutur sehingga penilaian baik dan tidaknya kesan makian ini bergantung pada konteks yang menyertainya.
Contoh (1)

Konteks: B memanggil temannya yang tidak menghiraukan suara azan di masjid, teman-teman B tersebut terus bersenda gurau.

B : Oe La maimo to inte dia kua masigi, Eara i kaffiri fana atu (Oe La mari kita pergi sekarang ke masjid, jangan kalian kafir seperti itu). 
Penggunaan kata makian kaffiri pada contoh (1) dalam konteks bercanda dengan teman-teman sebaya B. Penggunaan makian tersebut karena adanya keakraban di antara penutur dan petutur sehingga kata makian tersebut tidak mengganggu perasaan petutur. Kata makian kaffiri (kafir) bermakna 'tidak percaya kepada Allah Swt. dan rasulnya'. Makian kaffiri yang diucapkan oleh B karena teman-teman B tidak memedulikan suara azan di masjid. Mereka masih tetap asyik dengan kegiatan masing-masing.

\section{Contoh (2)}

Konteks: Seorang ibu yang sakit hati kepada

anaknya yang telah mencuri uangnya.

Ibu :Te ana haramu nai ko'o atu, paka umatemo ala'a di intenga iso

(Anak haram kamu itu, kenapa kamu tidak mati saja di jalan sana).

Kata makian haramu pada contoh (2) dalam konteks marah. Seorang Ibu yang sedang meluapkan kemarahannya kepada anaknya dengan menuturkan kata makian haramu. Kata makian tersebut merupakan makian negatif karena terjadi pada konteks marah. Kata makian haramu (haram) bermakna 'dilarang oleh hukum, tidak halal'. Makian haramu yang diucapkan oleh ibu karena si anak mencuri uang ibunya.

\section{Makian yang Bertalian dengan Makhluk Gaib}

Karakteristik makian pada jenis ini merupakan makian yang diungkapkan karena penutur mempunyai persepsi bahwa petutur memiliki karakter atau sifat seperti makhluk halus yang dimaksud.
Contoh (3)

Konteks: Rn muncul mendadak di depan teman-temannya dengan menggunakan bedak dingin.

Rn : Astaga, afanamo ala'a onitu da'o naiko'o atu. Nggala salam, $\mathrm{Fa}$

(Astaga, seperti hantu buruk rupa saja kamu itu. Beri salam dulu, $F a$ ).

Kata makian onitu da'o pada contoh (3) berada dalam konteks akrab. Seorang penutur yang sedang meluapkan perasaan kagetnya kepada petutur dengan menuturkan kata makian onitu da'o. Kata makian onitu da'o (hantu buruk rupa) bermakna 'roh jahat yang berada di tempat-tempat tertentu, kemunculannya mendadak'. Makian onitu da'o diucapkan oleh $\mathrm{Rn}$ karena temannya tiba-tiba muncul di hadapannya dengan muka yang berlumur bedak dingin dan tanpa memberi salam.

Contoh (4)

Konteks: Yn memukul Ar karena Ar jalan berduaan dengan pacar Yn.

Yn : Te binata nai ko'o atu. Te sai nu pongko na sai'u atu. Masa ko mala'e na popoilungkene nu kene'u sendiri

(Dasar binatang, kamu itu. Sifatmu itu sifatnya parakang. Bisa-bisanya kamu ambil pacarnya temanmu sendiri).

Kata makian pongko pada contoh (4), dalam konteks marah/geram. Seorang penutur yang sedang meluapkan perasaan geramnya kepada petutur dengan menuturkan kata makian pongko. Kata makian pongko (parakang) bermakna 'manusia jadi-jadian yang sering memakan anak atau orok, baik yang baru lahir atau masih dalam kandungan'. Makian pongko yang diucapkan oleh Yn karena Ar jalan 
berduaan dengan pacar Yn sehingga Yn merasa Ar merebut pacarnya.

\section{Makian yang bertalian dengan kelamin}

Makian ini dituturkan dengan menyebutkan salah satu nama kelamin, baik itu kelamin perempuan atau kelamin laki-laki. Makian tersebut muncul karena keberadaannya atau sifatnya yang tabu penamaannya di masyarakat.

\section{Contoh (5)}

Konteks: Fl memaki pacarnya karena selingkuh dengan teman akrab $\mathrm{Fl}$.

Fl : Te uni nu i ina sida, no ha'a usai akufana atu? kiki'i ara u dahani'e

("Vagina mamamu" betul, kenapa kamu buat saya seperti itu? sakit kalau kamu tahu).

Makian uni nu $i$ ina pada contoh (5) dalam konteks marah karena sakit hati. Seorang penutur yang sedang meluapkan perasaan sakit hatinya kepada petutur dengan menuturkan makian uni nu i ina. Makian uni nu i ina (kemaluannya mamamu/vagina) bermakna 'saluran antara leher rahim dan alat kelamin perempuan'. Makian uni nu $i$ ina yang dituturkan oleh $\mathrm{Fl}$ karena pacarnya berselingkuh dengan teman akrab Fl. Fl merasa tersakiti dengan perbuatan pacar dan temannya tersebut. Makian uni nu i ina merupakan makian kasar yang dianggap tabu oleh masyarakat Kaledupa dan tidak sembarang untuk dituturkan.

$$
\text { Penggunaan makian dalam }
$$

golongan jenis kelamin berkedudukan kasar karena sifatnya yang tabu. Bagi orang Kaledupa menuturkan makian yang bertalian dengan kelamin tidak pantas. Makian ini muncul karena penutur merasa marah, geram, jengkel dan sudah tidak terbendung lagi emosinya.

\section{Makian yang bertalian dengan bagian tubuh}

Makian ini dituturkan dengan menyebutkan salah satu bagian tubuh. Jenis makian ini ada yang berupa kata dasar, sebagian mendapat enklitika pronomina orang kedua $(-m u)$, dan frasa nomina.

Contoh (6)

Konteks: Vv dikasi kaget oleh temannya dari belakangnya.

Vv : Te fatu nu kapala'u sida, bara bo'uaku tuttu'e di atu

("Dasar kepalamu" betul, nanti saya tumbuk kamu di situ).

Penggunaan makian fatu $n u$ kapala'u pada contoh (6) dalam konteks jengkel. Seorang penutur yang sedang meluapkan perasaan jengkel karena kaget kepada petutur dengan menuturkan makian fatu nu kapala'u. Makian fatu nu kapala'u (batu kepala) bermakna 'bagian tubuh di atas leher'. Makian fatu nu kapala' $u$ yang diucapkan oleh Vv karena dia merasa jengkel, temannya mengagetkannya dari belakang. Kata fatu berarti 'batu' sedangkan kapala berarti 'kepala'. Penggunaan kata fatu merupakan penegasan kata kapala. Penggunaan makian ini juga bersifat makian rendah bergantung pada konteks yang menyertainya.

\section{Makian yang bertalian dengan fungsi tubuh}

Makian ini dituturkan dengan menyebutkan salah satu fungsi tubuh. Jenis makian ini ada yang berupa kata sifat (adjektiva) dan julukan.

Contoh (7)

Konteks: Dn memarahi Mg karena sering keluar rumah dan jarang pulang ke rumah.

Dn : Umina ala'a di umpa nai? $k o$ 'o atu fapande fila

(Kamu dari mana sajakah? kamu itu $F a$ Tukang Jalan). 
Penggunaan kata makian pande fila pada contoh (7) dalam konteks jengkel dan marah. Seorang penutur yang sedang meluapkan perasaan jengkel karena tidak suka dengan perilaku $\mathrm{Mg}$ yang sering keluar rumah bahkan jarang pulang. Kata makian pande fila 'si tukang jalan' bermakna sifat atau sikap yang tergambar dari tindakan seseorang, yakni sering jalan tanpa tujuan yang pasti (sekadar mencari kesenangan).

\section{Makian yang bertalian dengan bentuk tubuh}

Makian ini dituturkan dengan menyebutkan salah satu bentuk tubuh yang mengarah pada bentuk yang dominan menjadi ejekan masyarakat setempat. Jenis makian ini ada yang berupa kata dasar adjektiva dan frasa adjektiva.

\section{Contoh (8)}

Konteks: Ss memanggil temannya yang memakai rok tipis sehingga bentuk bokong besarnya kelihatan dengan jelas.

Ss : Fa tambi-tambi ulli ko'uminte kua umpa?

(Fa, bokong besar. Kamu mau pergi ke mana?)

Penggunaan kata makian ulli pada contoh (8) dalam konteks akrab. Seorang penutur yang sedang meluapkan perasaan risihnya karena melihat temannya yang menggunakan rok ketat. Kata makian ulli (bokong besar) bermakna 'bagian pangkal paha dengan ukuran yang besar mengapit dubur'. Makian ulli yang ditututrkan oleh Ss karena Ss merasa risih. Kata makian ulli merupakan interpreatsi orang Kaledupa terhadap bokong (pantat) dengan ukuran besar dan menonjol ke luar. Bagi orang Kaledupa merupakan sesuatu yang memalukan dan julukan yang bersifat negatif. Makian yang berupa julukan ini digunakan dalam konteks santai jika antara penutur dan petutur sudah akrab. Namun, jika antara penutur dan petutur tidak akrab akan mengundang perasaan marah salah satu pihak.

\section{Makian yang bersinonim dengan kata bodoh}

Makian ini dituturkan dengan menyebutkan kata-kata yang bersinonim dengan kata bodoh. Jenis makian ini ada yang berupa kata dasar adjektiva dan frasa adjektiva.

Contoh (9)

Konteks: Seorang paman memanggil keponakannya yang tidak bisa mengerjakan tugas sekolahnya.

Paman : Mai karaka ku gurukko, bara u kurafana atu

(Mari saya ajar kamu, jangan kamu bodoh begitu).

Penggunaan kata makian kura pada contoh (9) dalam konteks akrab, yakni seorang paman yang memperhatikan gelagat keponakannya yang bingung mengerjakan tugas sekolahnya. Kata makian kura bersinonim dengan kata pei (bodoh) bermakna 'tidak mudah mengerti, tidak mudah mengerjakan sesuatu'. Kata makian kura digunakan oleh penutur merupakan hal yang wajar karena adanya keakraban, seorang paman dan punya kuasa (lebih tua) dari keponakannya. Penggunaan kata makian ini disesuaikan dengan konteks yang menyertainya. Artinya, kata kura, pe'i, kabeo-beo dapat muncul di segala konteks, seperti saat mengumpat teman, marah, jengkel, geram, bercanda, dan sebagainya. 


\section{Makian yang bertalian dengan nama binatang}

Model makian yang mengacu pada binatang yang ditetapkan karena adanya kemiripan sifat atau perilaku binatang yang dimiliki oleh manusia.

\section{Contoh (10)}

Konteks: Ibu Ad yang memarahi tetangganya yang membuang kotoran di samping rumah sehingga Ibu tersebut ikut mencium bau busuk kotoran tersebut.

Ibu Ad : Ibbara u fikiri fana umpa nai ko'o atu ina La Sardi? Inta afana sai nu obu. Masa i kabi te ta'i di langketa

(Bagaimana pikiran kamu itu mamanya Sardi? Betul-betul seperti kelakuan anjing. Masa kamu buang kotoran (tai) di samping rumah).

Penggunaan kata makian obu pada contoh (10) dalam konteks jengkel, yakni Ibu Ad merasa jengkel kepada tetangganya yang sering membuang kotoran anaknya di samping rumah sehingga bau tidak sedap tercium sampai di rumahnya Ibu Ad. Kata makian obu (anjing) bermakna 'binatang berkaki empat, biasa dipelihara untuk berburu' Kata makian obu digunakan oleh penutur karena dalam pengertian dan pemahaman umum orang Kaledupa, anjing merupakan binatang yang mengandung najis berat dan berstatus haram dalam Islam. Penggunaan julukan makian yang bertalian dengan nama binatang dapat muncul di segala konteks seperti saat mengumpat teman, marah, jengkel, geram, bercanda, dan sebagainya.

\section{Makian yang bertalian dengan nama orang bodoh, gila, dan dungu}

Makian ini dituturkan dengan menyebutkan penyebutan nama orang bodoh, gila, dan dungu di daerah tersebut. Jenis makian ini ada yang berupa kata nomina.

\section{Contoh (11)}

Konteks: Ss melihat fotonya Az yang membuat Ss tertawa.

Ss : hahaha, u ha'amo, La Anjo? (hahaha, bagaimana kabarmu, La Anjo?)

Penggunaan kata julukan makian La Anjo pada contoh (11) dalam konteks bercanda. Ss menjuluki Az dengan nama orang bodoh di Kaledupa. Pemberian julukan makian tersebut digunakan dengan tujuan bercanda, merekatkan keakraban. Secara umum, masyarakat Kaledupa sering menjadikan julukan nama orang yang mempunyai keterbelakangan mental sebagai makian kepada sesama teman. Penggunaan julukan makian yang bertalian dengan nama orang yang mempunyai keterbelakangan mental dapat muncul dalam konteks seperti saat mengumpat teman, jengkel, bercanda, dan sebagainya.

\section{Makian yang bertalian dengan kekerabatan}

Makian ini dituturkan dengan menyebutkan penyebutan anggota keluarga. Jenis makian ini ada berupa kata dasar yang mendapat enklitika pronomina orang kedua $(-m u)$.

\section{Contoh (12)}

Konteks: Js memotong bicara Er karena jengkel dengan omongannya yang ngawur.

Js : Ama'u, Bara u koruo bisara! (Bapakmu, jangan kamu banyak Bicara!)

Penggunaan kata julukan makian ama' $u$ pada contoh (12) dalam konteks jengkel dan geram. Js memaki Er dengan panggilan kerabat (orang tua). Penggunaan makian tersebut digunakan 
pada saat perasaan jengkel, bercanda, marah, dan sebagainya.

\section{Makian yang bertalian dengan profesi rendah}

Makian yang mengacu pada profesi pekerjaan yang dianggap rendah/hina di mata masyarakat.

\section{Contoh (13)}

Konteks: Jn membicarakan tetangganya yang sering pulang malam dalam keadaan mabuk dan sering bertengkar dengan istrinya.

Jn : Sauri duka na pammoro'uno nai La Jono iso, no faliako kala di utu atu no pogiramo auka kene belano (Terlalu juga peminumnya itu, La Jono. Saat dia pulang malam pasti bertengkar lagi dengan istrinya).

Penggunaan kata makian yang bertalian dengan profesi rendah pada contoh (13) adalah kata pamoro'u. Kata makian tersebut digunakan dalam perasaan jengkel, yakni kejengkelan Jn terhadap kelakuan Jono yang tiap malam hanya minum-minum keras. Makian yang bertalian dengan profesi rendah tersebut akan sering digunakan jika profesi rendah tersebut merupakan tindakan rutin yang dilakukan oleh seseorang.

\section{Makian yang bertalian dengan suku/etnis}

Makian yang mengacu pada suatu suku/etnis yang di mata masyarakat suku/etnis tersebut berada pada lapisan bawah masyarakat Kaledupa.

Contoh (14)

Konteks: Nn memarahi anaknya yang pengotor dan malas membersihkan rumah.
Nn : Afana sai nu fadu na pakkotoro'u atu, bisa te sombure'a nu sapo umallasi. (Seperti perilakunya Bajo pengotormu itu, untuk menyapu srumah pun, kamu malas).

Penggunaan kata makian yang bertalian dengan suku/etnis pada contoh di atas adalah kata $f a d u$. Kata makian tersebut digunakan dalam perasaan jengkel, yakni kejengkelan $\mathrm{Nn}$ terhadap kelakuan anaknya yang pengotor dan pemalas. Munculnya kata makian $f a d u$ merupakan suatu presepsi sebagian masyarakat Kaledupa terhadap suku Bajo-pengotor, kampungan, dan terisolir-sehingga jika ada keadaan yang menggambarkan kebiasaan Bajo tersebut, sebagian masyarakat Kaledupa akan menggunakannya sebagai makian.

\section{Makian yang bertalian dengan asal daerah terpencil}

Makian yang mengacu pada letak suatu daerah asal penutur. Daerah tersebut berada di bagian terpencil daerah Kaledupa sehingga orang yang berasal dari daerah terpencil tersebut selalu mendapat julukan negatif dari masyarakat kota Kaledupa.

\section{Contoh (15)}

Konteks: Kk menilai penampilan orang yang sedang lewat di depan rumahnya. Orang tersebut penampilan pakaiannya sangat warna warni.

$\mathrm{Kk}$ : Adde, bangunomo te ammai kollo, bisa te Eajuno afana pelangi.

(Astaga, jangan heran mereka itu orang kebun

[pelosok/terpencil], biar bajunya seperti pelangi). 
Penggunaan kata makian yang bertalian dengan asal daerah terpencil pada contoh (15) adalah frasa ammai kollo. Frasa makian tersebut digunakan sebagai sindiran, yakni sindiran $\mathrm{Kk}$ terhadap orang yang sedang lewat di depan rumahnya dengan pakaian yang warna-warni. Frasa ammai kollo bermakna 'orang yang berasal dari pelosok yang dominan masih berpikiran kampungan atau tradisional'. Munculnya frasa makian ammai kollo merupakan presepsi sebagian masyarakat Kaledupa terhadap orang-orang yang dari pelosok bahwa mereka itu tidak tahu berdandan, pakaian tidak rapi, dan sebagainya.

\section{Makian yang bertalian dengan benda abstrak}

Makian yang mengacu pada benda abstrak merupakan makian yang muncul dalam keadaan marah, jengkel, geram, dan dapat pula dalam keadaan bercanda dan keakraban.

\section{Contoh (16)}

Konteks: $\mathrm{Kr}$ kaget melihat Ss ada di depan rumahnya, setahu $\mathrm{Kr}$, Ss pergi kuliah di Baubau.

$\mathrm{Kr}$ : Kalea, urato dihia? (Kalea, kamu tiba kapan?)

Penggunaan kata makian yang bertalian dengan benda abstrak pada contoh (16) adalah frasa kalea. Kata makian dalam konteks tersebut digunakan sebagai rasa kaget, rasa akrab, yakni rasa kaget $\mathrm{Kr}$ terhadap Ss yang tiba-tiba muncul atau datang ke rumah $\mathrm{Kr}$.

\section{Makian yang bertalian dengan penyakit yang menjangkiti subjek}

Makian yang mengacu pada penyakit yang menjangkiti subjek sering digunakan oleh masyarakat Kaledupa. Hal ini sudah menjadi kebiasaan turuntemurun. Makian ini terkadang menimbulkan kemarahan dari subjek yang menderita penyakit tersebut.

\section{Contoh (17)}

Konteks: Pn menceritakan temannya kepada Ibunya.

$\mathrm{Kr} \quad$ : Fa, Ina tei la Udi pamo atto'e no ekkamo dihaji'a.

( $\mathrm{Fa}$ Mama, itu La Udi Panuan sudah pergi Haji).

Penggunaan kata makian yang bertalian dengan nama penyakit yang menjangkiti subjek pada contoh (17) adalah kata pamo. Kata pamo dalam bahasa Indonesia bermakna 'panu'. Kata makian dalam konteks tersebut digunakan sebagai sebuah identitas atau julukan pada subjek. Munculnya makian tersebut sebagian tidak didasarkan karena untuk memaki. Namun, hal ini sering juga digunakan untuk mengolokolok.

\section{PENUTUP}

Berdasarkan hasil penelitian dalam pembahasan, dapat disimpulkan beberapa hal yang menjadi temuan dalam penelitian jenis makian dalam bahasa Wakatobi dialek Kaledupa.

Terdapat lima belas jenis makian dalam bahasa Wakatobi dialek Kaledupa, yakni (1) makian yang bertalian dengan agama/kepercayaan ditemukan dalam bentuk kata nomina dan kata adjektiva; (2) makian yang bertalian dengan gaib ditemukan dalam bentuk kata nomina dan frasa nomina; (3) makian yang bertalian dengan kelamin ditemukan dalam bentuk kata nomina dan frasa nomina; (4) makian yang bertalian dengan bagian tubuh ditemukan dalam bentuk kata nomina dan frasa nomina; (5) makian yang bertalian dengan fungsi tubuh ditemukan dalam bentuk gramatikal dan kata nomina; (6) makian yang bertalian dengan bentuk tubuh ditemukan dalam 
bentuk kata adjektiva dan frasa adjektiva; (7) sinonim kata bodoh ditemukan dalam bentuk kata adjektiva dan frasa adjektiva; (8) makian yang bertalian dengan nama binatang ditemukan dalam bentuk kata nomina dan frasa nomina; (9) makian yang bertalian dengan nama orang dungu ditemukan dalam bentuk kata nomina; (10) makian yang bertalian dengan kekerabatan ditemukan dalam bentuk kata nomina; (11) makian yang bertalian dengan profesi rendah ditemukan dalam bentuk kata nomina; (12) makian yang bertalian dengan suku/etnis ditemukan dalam bentuk kata nomina; (13) makian yang bertalian dengan asal daerah terpencil ditemukan dalam bentuk frasa nomina; (14) makian yang bertalian dengan benda abstrak ditemukan dalam bentuk kata nomina; (15) makian yang bertalian pada penyakit yang menjangkiti subjek ditemukan dalam bentuk kata nomina. Berbagai jenis makian tersebut ditemukan dalam bentuk peranti linguistik seperti kata, frasa, dan bentuk gramatikal.

\section{DAFTAR PUSTAKA}

Alwi, H., et al. (2008). Kamus besar bahasa Indonesia. Jakarta: PT Gramedia Pustaka Utama.

Anderson, L. W., David R., \& Krathwohl. (2010). Kerangka landasan untuk pembelajaran, pengajaran, dan asesmen (Revisi taksonomi pendidikan Bloom). Yogyakarta: Pustaka Pelajar.

Jannah, Almaidatul, Wahyu, W., \& Kusmiyati. (2017). Bentuk dan makna kata makian di terminal Purabaya Surabaya dalam kajian Sosiolinguistik. Jurnal Fonema, 4(2), 43-59).
Kartono, K. (1980). Pengantar metodologi research sosial. Bandung: Alumni.

Kisyani. 2004. Bahasa Jawa di Jawa Timur bagian utara dan Blambangan. Jakarta: Pusat Bahasa, Departemen Pendidikan Nasional.

Kusmana, A. \& Afria, R. (2018). Analisis ungkapan makian dalam bahasa Kerinci: Studi Sosiolinguistik. Jurnal Ilmu Humaniora, 02(02), 173-192.

Moleong, L. (2007). Metodologi penelitian kualitatif. Bandung: Remaja Rosdakarya.

Sibarani, R. (2004). Antropolinguistik: Antropologi Linguistik, Linguistik Antropologi. Medan: Poda.

Susiati. 2018. Hominimi bahasa Kepulauan Tukang Besi dialek Kaledupa. Jurnal Totobuang, 6(1), 109-123).

Triadi, R. B. (2017). Penggunaan makian bahasa Indonesia pada media sosial (Kajian Sosiolinguistik). Jurnal Sasindo Unpan, 5(2), 126.

Wijana, I. D. P. \& Muhammad, R. (2006). Sosiolinguistik: Kajian teori dan analisis. Yogyakarta: Pustaka Pelajar.

Winarsih, T. (2010). Pisuhan dalam 'Basa Suroboyoan': Kajian Sosiolinguistik. Tesis. Surakarta: UNS. 